\title{
A Framework towards Assessing the Merits of Inviting IT Professionals to the Classroom
}

\author{
Faouzi Kamoun and Said Selim \\ College of Information Technology, University of Dubai \\ Dubai, UAE
}

\section{fkamoun@ud.ac.ae sselim@ud.ac.ae}

\section{Executive Summary}

For the past years, the academic IT profession through various professional society curriculum committees and accreditation bodies has made considerable progress to revise and update IT curricula to meet the changing needs of the profession. In particular, learning techniques, beyond classroom teaching activities, have been recognized as essential ingredients to enhance the learning outcomes of advanced-level IT courses. This study outlines an assessment framework to explore the merits of inviting IT professionals as a pedagogical technique to integrate real world IT experience into the classroom. Though the general merits of inviting guest speakers have been confirmed in many previous (non-IT related) studies, these events are particularly much needed in the IT field. This urgency is justified by many factors such as the complex and constantly changing IT profession and its environment, the rapid pace in the rollout/phase-out of IT technologies and terminologies, and the shallow focus on professional orientation in most IT curricula. Our study confirms some of the merits of inviting guest speakers as reported in the literature. It also adds to existing literature in at least three aspects. First, to our best knowledge, this is the first reported study that reflects upon the usage of guest speakers in IT classrooms. Second, our research is a first initiative that contributes to establishing a formal framework for the planning and the assessment of guest speaker events. Such an assessment framework will be very useful for continuous improvement to ensure that students will not feel cheated that three hours of classtime lecturing and discussions were devoted to a less worthwhile guest speaker talk. Third, compared to previous studies, the experience reported in this article is unique in the sense that it is formally and strategically planned, conducted on a large (university-wide) scale and scheduled during a particular week near the end of each semester. Based on the proposed assessment framework and research methodology, this research makes use of multiple sources of evidence to assess the merits of guest speaker events.

The data collected indicate that the event helps remedy the lack of exposure of information technology students to the IT professional environment. The event can also provide students with invaluable real-world and practical IT knowledge. Such knowledge can either relate to a particu-

Material published as part of this publication, either on-line or in print, is copyrighted by the Informing Science Institute. Permission to make digital or paper copy of part or all of these works for personal or classroom use is granted without fee provided that the copies are not made or distributed for profit or commercial advantage AND that copies 1) bear this notice in full and 2) give the full citation on the first page. It is permissible to abstract these works so long as credit is given. To copy in all other cases or to republish or to post on a server or to redistribute to lists requires specific permission and payment of a fee. Contact Publisher@InformingScience.org to request redistribution permission. lar topic already covered by the course, or it can bring new practical perspectives which are not covered by the course syllabus. These perspectives, along with the guest speaker recommendations, can be fed-back into the IT courses to enrich their content and/or scope. Such feedback is more important than ever given the rapidly evolving nature of the IT environment. This study 
also revealed that, in our case, the event did not contribute much towards exposing students to ethical and/or cultural issues related to the workplace. The authors believe that this shortcoming could be addressed by sharing with guest speakers the event's objectives and requesting their support to achieve them. Our research also underlines the need for formal frameworks to assess the learning outcomes of guest speaker events. Event objectives, performance criteria and measurement indicators should be clearly defined. Careful planning, judicious implementation, based on best practices, and thorough assessment are some basic ingredients for successful guest speaker events. These requirements need to be integrated in the overall assessment strategy of the program curriculum. The assessment tools and research methods presented in this study can be very useful for IT faculty planning to conduct similar guest speaker events in future. Future research could focus on refining the event's assessment criteria by incorporating the objectives outlined in the various IT professional curriculum reports. Similar studies can also be conducted to confirm whether the findings of this study still hold in other institutions.

Keywords: IT education, IT practitioners, guest speakers, speaker events, assessment framework.

\section{Introduction}

Many IS professional society curriculum reports stress the fact that IS students must be exposed to broad business and real world perspectives. For instance, the 2002 ACM/AIS/AITP Information Systems undergraduate curriculum report (Gorgone, Davis, Valacich, Topi, Feinstein, \& Longenecker, 2002) asserts that there is a growing need to maintain an ongoing dialogue with IS professionals to improve the curriculum and the educational experience of students. It confirms that invited guest speakers, internships and advisory board members provide means to revitalize this dialogue.

Though the general merits of inviting industry professionals have been confirmed in many previous (non IT-related) studies, guest speaker events (thereafter abbreviated as GS events) are particularly much needed in the IT field. Maglitta (1996) reported that IS programs are struggling to keep up-to-date with the latest technologies and changes. GS events are seen as tools to bring about the needed changes in IT education. This can potentially help IT schools remedy the current limitations of their programs keeping pace with the complex and constantly changing IT profession and its environment. In fact, IT differs from many other disciplines in its dramatic changing nature. Many questions are being raised on what knowledge and skills should be taught in a field where new technologies and terminologies flourish and disappear. Unfortunately, the pace of change in curriculum redesign is lagging behind the rate of change in the IT field. For instance there has been a constant change in the selection of the most appropriate and up-to-date programming languages for IT applications. Further, the role of IT in supporting business strategies and operations has been evolving rapidly for the past years and will certainly continue to change. Trends such as near-shore and off-shore outsourcing of IT services and products, and the efficient usage of IT for business process re-engineering are still not well grasped by students. GS events can provide a means to supplement conventional teaching to expose students to recent trends and emerging technologies and practices. Kim, Shim and Yoon (1999) found that IS practitioners perceive managerial and organizational issues as being more important than educators do. They recommend that educators and practitioners should have a shared vision of key IS issues and collaborate on curriculum development by incorporating industry needs into the curriculum. This can also contribute towards narrowing the gap between what IT schools teach and what the practitioners in the field require. Previous research has shown that in a business educational context, students have a tendency to rate much lower any activities failing to relate directly to industry (Sivan, Leung, Woon, \& Kember, 2000). Students also demand a better balance between theory and practice and, in most cases, the use of guest speakers and real-life case studies remains the most popular suggestion (Clarke \& Gibson-Sweet, 1998). Students also enjoy listening to profes- 
sionals telling real work stories, especially when companies usually discard valuable information that universities cannot afford or that textbooks will not cover (Gustafson, 1998). Another factor that favors the need for guest speakers in IT programs is the wide spectrum of 'often blurred' career choices available for IT graduates. In fact the focus on professional orientation has generally been implicit in most IT curriculums. GS events provide a means to make such focus more explicit. The issue of exploring the many facets of inviting guest speakers into the classroom becomes even more significant when we acknowledge that poorly planned GS events will not only fail to fulfill their intended objectives, but can also lead to upsetting outcomes (Shore, 1993; Sniezek, 2005; Wortman, 1992). Thus it is one of the contributions of this research to establish a general framework to plan GS events and assess their learning outcomes. Such assessment framework will be very useful for continuous improvement to ensure that students will not feel cheated that three hours of class-time lecturing and discussions were possibly sacrificed for a speaker whose talk was of limited value.

Our study confirms the general merits of invited guest speakers as reported in the existing literature; although it adds to existing literature in many other aspects as shown in the next section.

\section{Literature Review and Research Contribution}

Previous studies and research suggest that invited GS events demonstrate new aspects of pedagogical innovation for curriculum enhancement. This section discusses the merits of GS events.

First, GS events have been viewed as a means to breakdown perceived artificial barriers between "academic" and "real-world" practice (Clarke \& Gibson-Sweet, 1998; Glenwick \& Chabot, 1991; Gordon, 1999). Davis (1993) recommends the usage of guest speakers, with pertinent expertise or practical experience, as an alternative to lectures. Boyer (1990) argues that the work of the professoriate needs to be related more to the world outside the campus, as a means of promoting the integration of knowledge. GS events provide an opportunity to achieve this need. Sandy (1998) promotes the idea of a permeable classroom which endorses the establishment of stronger connections between classroom material and the "real world". Among the four aspects of permeability that the author proposes, is the usage of guest speakers as a means to share first hand and practical knowledge with students and faculty. Lambert (2003) identified invited GS events as major engagements that facilitate knowledge creation and transfer between the higher education sector and industry. Within the context of knowledge management, Viehland (2005) quoted guest speakers as facilitators of knowledge sharing and knowledge reuse in communities of practices. Knowledge reuse is defined as sharing best practices or helping others solve technical problems (Markus, 2001). Ohl (1991) argues that professional practitioners make great guest speakers and that the practice of bringing them to the classroom constitutes an enlightening experience for them as well as for the university. Contemporary universities today are also expanding their teaching methods to reach a flexibility that emphasizes access and synergies with the real world (Gordon, 1999). Siemens (2004) proposes "connectivism" as a learning theory of the digital age, which is driven by the understanding that specialized sources of information in different communities can be connected together to ensure that learning activities are both accurate and current. GS events promote "connectivism" by being part of these specialized nodes of information sources. In doing so, GS events also endorse the notion of collaborative learning (Rae, Roberts, \& Taylor, 2007) to better prepare students for the "real-world".

Second, some research papers have explored the usage of guest speakers as career information providers and spokespersons for professional orientation. Several case studies have reported the successful usage of guest speakers to foster a positive attitude towards the profession. This can eventually help students stay motivated, focused and on track towards their career goals. GS events can also help students prepare for job interviews, and reassure them that they are studying the right subject (Metrejean, Pittman \& Zarzeski, 2002). Neville and Adam (2003) reported a 
case-study related to the usage of business simulation games in the classroom. In the study, industrial speakers with relevant expertise and experience were invited to share their ideas and stories with the class and helped students realize that the scenario developed for them is very close to what happens in reality, which further boosts their interest in the game. GS events also add value to existing educational programs by enhancing students' employability and hands-on knowledge, thus giving students a definite educational competitive advantage (Cooper, Bottomley, \& Gordon, 2004). Metrejean, Pittman \& Zarzeski (2002) highlighted that guest speakers can effectively be used to expose students to various field-oriented career information, which is typically missing from most textbooks. They suggested that students are not aware of all career paths they can pursue upon graduation and therefore invited guest speakers can expose students to various career opportunities. In addition, GS events can provide students with an opportunity to network with professionals who could provide future employment.

Third, GS events have been looked upon in some other studies (Murray \& Bollinger, 2001; Davis, 1993) as a potential tool to expose students to some strategies used by professional experts, though it is not expected to transform students from novices to experts. Such exposure is particularly important given the unique attributes of experts, such as their substantial degree of knowledge that is organized in a way that reflects a deep understanding of their subject matter. Experts can also see patterns in information not evident to novices and filter relevant information from irrelevant information (Bransford, Brown \& Cocking, 1999). Experts also differ from novices in their ability to self-regulate their time and efforts, focusing on goal setting, time management, self-evaluation and self-motivation (Cleary \& Zimmerman, 2000). Guest speakers can also use their expertise to clarify issues with which the lecturer may not be entirely familiar (Metcalfe, Wilson, \& Joham, 2002; Wortman, 1992).

Fourth, besides benefiting students, GS events provide faculty with an opportunity to keep abreast of the latest developments and challenges in the workplace. They also keep the practicing professionals accustomed to the educational environment (Wortman, 1992), giving these professionals an opportunity to contribute towards the enrichment of the content and scope of courses (Metrejean, Pittman \& Zarzeski, 2002), which for IT programs is much needed given the rapid pace of technology changes. IT professionals can in fact provide valuable feedback to universities concerning what areas of study and competencies are important (Caputo, Kovacs \& Turchek, 2006).

Fifth, GS events have also been reported as a means to boost the image of the university programs by showcasing the students and facilities to the outside public (Heck, 1994). They also benefit the university in many other ways, such as providing opportunities for possible internships and workstudy programs, fostering positive community relationships, and providing publicity through a series of contacts and networking (Wortman, 1992).

Other studies have also highlighted the successful use of guest speakers to raise students' ethical awareness, cultural sensitivity, and to challenge students' stereotypes (Berlak, 1999; Butler, 1997; Clarke \& Gibson-Sweet, 1998; Guth, Hewitt-Gervais, Smith, \& Fisher, 2000; Murray \& Bollinger, 2001). GS events can demonstrate the integration of ethical/cultural principles in the workplace into practice. Ethical and cultural issues include for instance privacy, justice, equality, intellectual property, diversity, responsibility, welfare, trust, obligations, and prejudice, among others. Butler (1997) also demonstrated how guest speakers can be used to compensate for cultural biases in the real world of business by reducing gender bias towards women in leadership positions.

This research confirms some of the merits of inviting industry professionals to the classroom as reported above and elsewhere (see for example Mullins, 2001; Ormrod, 2004; Payne, Sumter, \& Sun, 2003). It also adds to existing literature in at least three aspects. First, and to the best of our knowledge, all previous exploratory studies related to GS events were within the context of business, social sciences and humanities education. As a result, our research is unique in the sense 
that it is the first initiative that reflects upon the usage of invited guest speakers in IT education. This is particularly important given the unique nature of the IT field, as discussed in the previous section. Second, previous work related to inviting industry professionals to the classroom typically consisted of reported case studies that aimed to validate the merits of GS events. Some of these studies have shared some key success factors to support the efficient use of guest speakers in the classroom. These studies were particularly helpful for our current research as they provided us with valuable information related to some of the event best policies /practices, objectives, and learning outcomes. These are important elements in developing the GS event assessment process as outlined in the next section. However, what we felt was missing was the establishment of a formal framework to assess the learning outcomes of GS events. Thus, it is one of the key objectives of this study to sketch a framework for the assessment process. Such a framework can provide practical guidance for other IT educators to assess and continuously improve the learning outcomes of GS events.

Finally, compared to most previous studies which were often of ad-hoc in nature, the experience reported herein is unique in the sense that it is formally and strategically planned, conducted on a university-wide scale and scheduled during a particular week near the end of each semester.

\section{Assessment Framework}

It was clear from our earlier experimentation with GS events that the assessment of the learning outcomes of these GS events was not a simple task. Without any prior framework, we realized that we cannot easily find qualitative or quantitative indicators that would tell us whether any type of learning is taking place. As a result, a framework for the planning and assessment process was deemed necessary. For this purpose we have adopted a design-oriented approach to assessment planning and have established an assessment framework based on the combination of our own experience with curriculum assessment in general and some commonly established selfevident knowledge. In particular, we were inspired by our own model for curriculum assessment planning which aims to assess the learning outcomes at the program level. We have then adapted our own curriculum assessment process to outline the general assessment framework for the GS events. Here the focus has shifted from assessing an academic program as a whole to assessing a GS event. The proposed assessment framework can be conceptualized in terms of three interdependent and interlocking elements (shaded phases in Figure 1). These core phases are analysis and planning, implementation and assessment feedback.

We first outline the general framework, based on the above three sequential broad headings. As shown in Figure 1, the GS event assessment process begins with analysis and planning. The event purpose and priorities are articulated, event goals identified and these are fleshed out into more meaningful objectives; appropriate research and assessment methods, as well as assessment measures are also selected. Next, the implementation phase translates the chosen methodology into action through the allocation of budget and resource and the usage of best policies and practices. Finally, the assessment feedback phase closes the loop by assessing the event learning outcomes and feeding the results into the next round of assessment formulation. The feedback loop, illustrated in Figure 1, shows that the assessment process is ongoing and cyclical.

In the remainder of this section we elaborate in more details on each of the eight items which are associated with the core phases of the assessment process. 


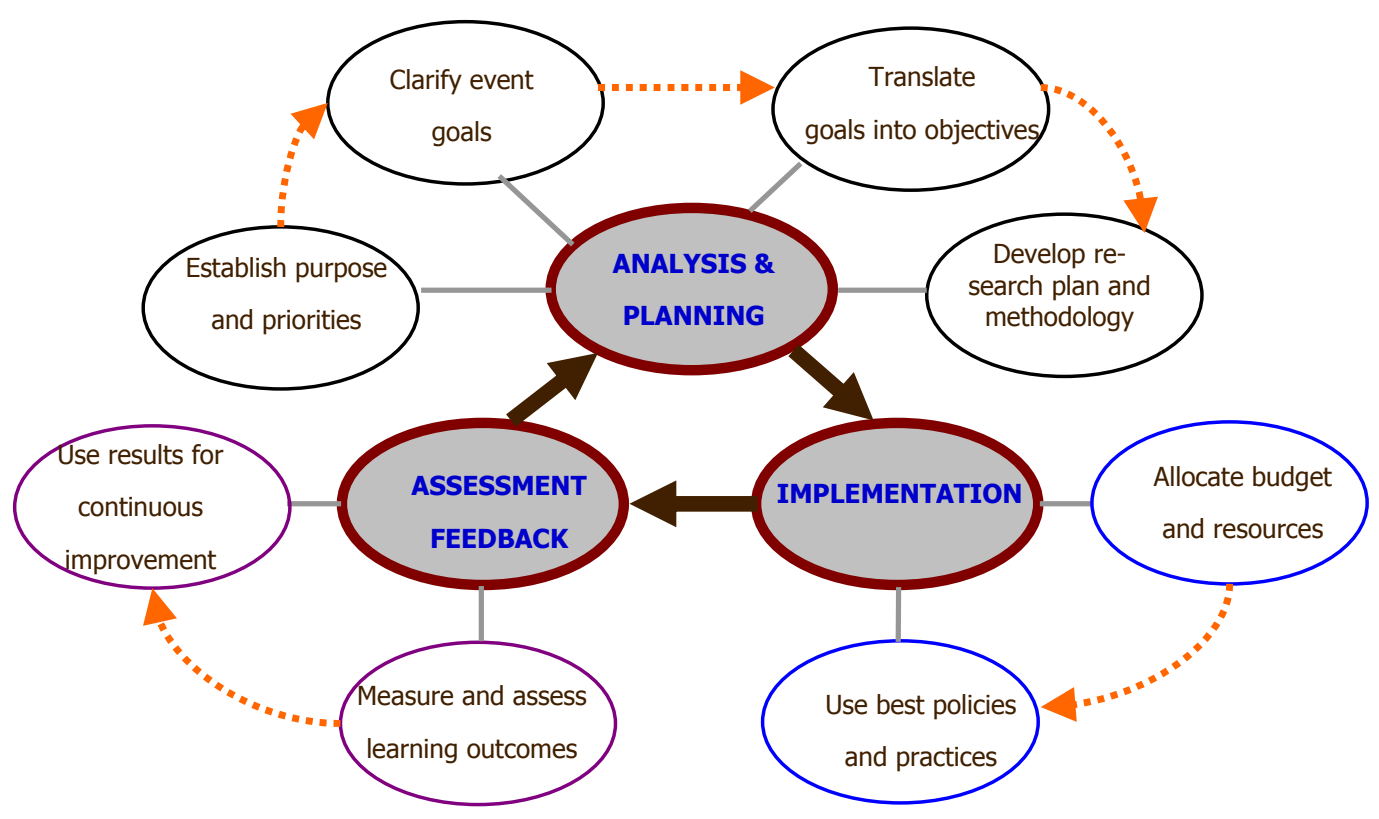

Figure 1: A framework for the assessment process

\section{Analysis and Planning Phase}

The first step in the analysis and planning phase is to establish the purpose and priorities of the GS event. Since this event consumes valuable time and requires some resources to be allocated, it is imperative that the event's organizing committee conveys a clear message on why the department is initiating the program. Faculty must have reasons to believe that the benefits of the GS event surpass the costs. They must be convinced that the time taken from their regular teaching class in addition to the time they spend to identify suitable guest speakers and coordinate for the event are well spent. Meetings to convey the purposes and objectives of invited GS events should be conducted. These gatherings can take the form of informal seminars, departmental meetings or one-to-one faculty encounters. Further, incentives or reward mechanisms for faculty participation in the GS events should be established to promote faculty involvement.

The second and third steps in the analysis and planning phase consist of clarifying the event goals and translating these goals into more tangible objectives. These are important steps to enhance the positive impact of the events on students' learning. In fact, clearly articulated GS event goals and objectives build common understanding and agreement about what the event should accomplish and provide directions to assess the event's learning outcomes. Key stakeholders including faculty, students, advisory boards and the speaker event committee can contribute towards setting the goals of the event. In addition, research findings related to GS events, such as those reported in the previous section, have been valuable resources to formulate and prioritize those event goals which are most suited for our organization. We have consulted the pertinent literature outlined in the previous section to develop meaningful and measurable outcomes and benefited from the findings of many case studies where similar types of GS events have been reported. Based on the above we have identified three main goals and twelve main objectives for GS events as shown in Table 1 . 
Table 1: Guest speaker event goals and objectives

\begin{tabular}{|l|l|}
\hline \multicolumn{1}{|c|}{ Speaker event goal: } & \multicolumn{1}{c|}{ Speaker event objectives } \\
\hline $\begin{array}{l}\text { Student will demonstrate an understanding of } \\
\text { real-world practical knowledge }\end{array}$ & $\begin{array}{l}\text { Student will relate course-work to applications } \\
\text { in a real world setting }\end{array}$ \\
$\begin{array}{l}\text { Student will be able to identify new trends in } \\
\text { IT } \\
\text { Student will be able to identify strategies used } \\
\text { by professional IT experts } \\
\text { Student will be able to identify and analyze } \\
\text { ethical and cultural issues related to the work- } \\
\text { place }\end{array}$ \\
\hline $\begin{array}{l}\text { Student will identify new practical facts re- } \\
\text { lated to their professional orientation }\end{array}$ & $\begin{array}{l}\text { Student will be exposed to some characteris- } \\
\text { tics of professional role models }\end{array}$ \\
$\begin{array}{l}\text { Student will be able to recognize new IT ca- } \\
\text { reer paths and opportunities }\end{array}$ \\
$\begin{array}{l}\text { Faculty will get exposed to real-world IT } \\
\text { practices and trends and will demonstrate their } \\
\text { integration into their courses }\end{array}$ & $\begin{array}{l}\text { Student will be able to identify what areas of } \\
\text { IT competencies are important } \\
\text { Student will demonstrate a more positive atti- } \\
\text { tude towards the IT profession }\end{array}$ \\
$\begin{array}{l}\text { Student will acquire the opportunity to net- } \\
\text { work with IT professionals }\end{array}$ \\
$\begin{array}{l}\text { Faculty will be able to keep abreast with the } \\
\text { IT profession and its environment } \\
\text { Faculty will be able to identify some latest } \\
\text { practices and trends in the IT industry } \\
\text { Faculty will acquire the opportunity to incor- } \\
\text { porate concepts, facts and ideas acquired from } \\
\text { the event into their courses }\end{array}$ \\
\hline
\end{tabular}

We also observed that the main goal behind knowledge transfer from the real world to the classroom, as reported in previous studies, has been to align the speaker talk with a particular topic already listed in the course syllabus. We believe that organizers of GS events should also experiment with an impacting (in addition to aligning) strategy, whereby the speaker talk brings new dimensions and perspectives which are not covered by the course syllabus. This is particularly needed in the IT field given its rapidly changing nature and the emergence of new IT technologies and solutions which are not yet covered by textbooks. The impacting strategy will also contribute in incorporating industry needs into IT curricula, as dictated by the nature of the field. We therefore recommend that the relationship be reciprocal as shown in Figure 2.

The fourth step in the analysis and planning phase is to develop a research plan and methodology. For this purpose, concurrent as well as retrospective inquiry methods have been used to assess the merits of the GS event. The assessment instruments will focus on the GS event outcomes as well as its environment. Further details on the research methodology will be provided in the next section. 


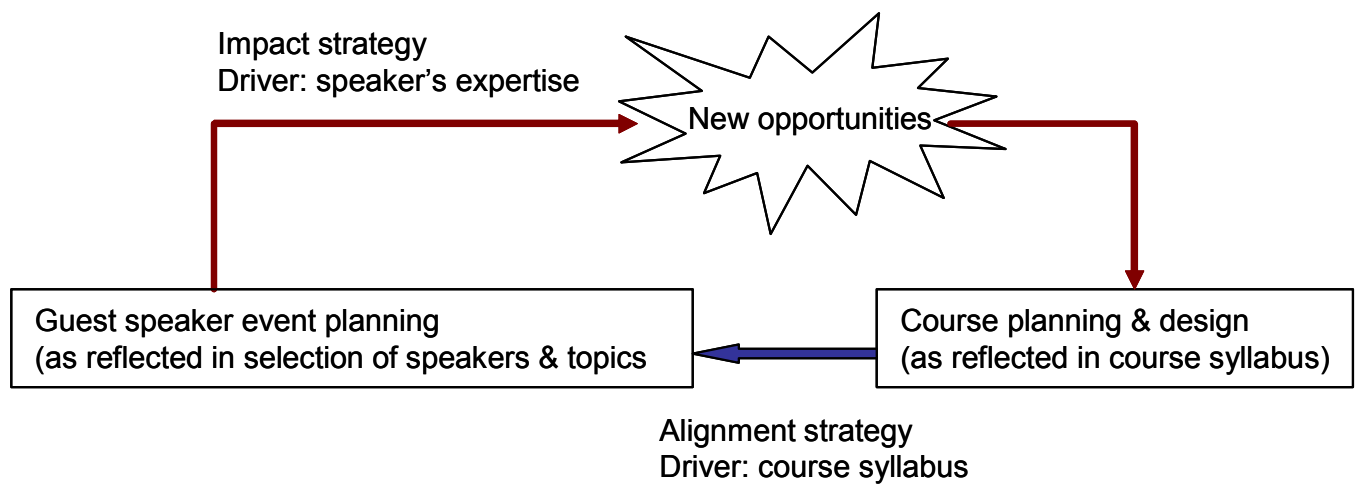

Figure 2: Alignment versus impacting framework

\section{Implementation Phase}

The first step in the implementation phase is to allocate budget and resources for the GS event. This step, often overlooked in existing literature, is essential in order to define the scope of the GS event and secure enough funding and resources for its successful completion. This task should be the responsibility of the administration, in consultation with the event's organizing committee. The cost of the GS event includes administration cost, opportunity cost for faculty and others involved, data handling/storage/analysis cost, logistics cost, marketing cost and incentive cost for the invited speakers and faculty. All these cost items need to be factored into the budget.

The second step is that of making use of the best policies and practices. Our literature research, reported in the previous section, combined with lessons learned from our past three-years experience with GS events, have guided us in compiling a list of best policies and practices. These are shown in Appendix A.

\section{Assessment Feedback Phase}

Assessment feedback begins with measuring and assessing the event learning outcomes. We have classified these outcomes into three categories: practical knowledge, attitude towards the IT profession, and career awareness. For the purpose of assessment, it is necessary to collect, analyze and summarize the gathered data. The following assessment methods can be used to gauge students' learning from the GS event:

- Students' self-report questionnaires. These include open-ended questions, as well as students' ratings of agreement with statements of values and attitudes. Both current and senior graduating students are targeted in the surveys.

- Instructor observation of interpersonal interactions between students and guest speakers

- Faculty and invited speaker surveys.

- Instructor-led open discussions with students just after the GS event and before graduation

- Students' debriefing summaries on learning outcomes.

- Students' performance on assignments and/or final exam questions related to the GS event

Students' perception of the GS events has also been assessed at two strategic points in their experience, namely, just after the event and upon graduation. 
In addition to outlining the general assessment methods, it is also important to develop and validate performance-based measures and indicators for each of the learning outcomes outlined in Table 1. For this purpose, brainstorming sessions have been used to gather the performance criteria articulated by the event's objectives. The results are shown in Table 2.

Table 2: Performance criteria and their assessment

\begin{tabular}{|c|c|c|}
\hline Objective & Performance criteria & Measurement indicator \\
\hline $\begin{array}{l}\text { Student will relate course-work to applications } \\
\text { in a real world setting } \\
\text { Student will be able to identify new trends in IT } \\
\text { Student will be able to identify strategies used } \\
\text { by professional IT experts } \\
\text { Student will be able to identify and analyze } \\
\text { ethical and cultural issues related to the work- } \\
\text { place } \\
\text { Student will be exposed to some characteristics } \\
\text { of professional role models }\end{array}$ & $\begin{array}{l}\text { Student articulates some aspects } \\
\text { of newly acquired real-world IT } \\
\text { knowledge } \\
\text { Student can relate theory learned } \\
\text { in class to professional examples } \\
\text { discussed during the event } \\
\text { Student is able to recognize and } \\
\text { list some new emerging trends in } \\
\text { IT } \\
\text { Student can successfully identify } \\
\text { some unique approaches and } \\
\text { strategies used by professionals }\end{array}$ & $\begin{array}{l}\text { Students' performance on assignment } \\
\text { and/or exam questions related to perform- } \\
\text { ance criteria. } \\
\text { Students' self-assessment as reported } \\
\text { though questionnaires } \\
\text { Overall rating of students' responses in } \\
\text { class discussions related to performance } \\
\text { criteria }\end{array}$ \\
\hline $\begin{array}{l}\text { Student will be able to recognize new IT career } \\
\text { paths and opportunities } \\
\text { Student will be able to identify what areas of IT } \\
\text { competencies are important } \\
\text { Student will demonstrate a more positive atti- } \\
\text { tude towards the IT profession } \\
\text { Student will acquire the opportunity to network } \\
\text { with IT professionals }\end{array}$ & $\begin{array}{l}\text { Student clearly identifies new } \\
\text { job opportunities offered to IT } \\
\text { graduates } \\
\text { Student can identify skill sets } \\
\text { and proficiencies that are most } \\
\text { needed for IT careers } \\
\text { Student is able to establish liai- } \\
\text { son with the guest speaker for } \\
\text { potential assistance with job } \\
\text { opportunities } \\
\text { Student feels more motivated } \\
\text { and on track to pursue the IT } \\
\text { profession }\end{array}$ & $\begin{array}{l}\text { Student self-assessment as reported though } \\
\text { questionnaires } \\
\text { Overall rating of students' responses in } \\
\text { class discussions related to performance } \\
\text { criteria } \\
\text { Percentage of students who benefited from } \\
\text { the networking opportunity to get a job } \\
\text { Faculty rating of students' comments and } \\
\text { debriefing summaries following the event. }\end{array}$ \\
\hline $\begin{array}{l}\text { Faculty will be able to keep abreast with the IT } \\
\text { profession and its environment } \\
\text { Faculty will be able to identify some latest prac- } \\
\text { tices and trends in the IT industry }\end{array}$ & $\begin{array}{l}\text { Faculty is made aware of emerg- } \\
\text { ing trends and practices in the IT } \\
\text { profession }\end{array}$ & $\begin{array}{l}\text { Rating of faculty responses on checklist } \\
\text { based on performance criteria }\end{array}$ \\
\hline $\begin{array}{l}\text { Faculty will acquire the opportunity to incorpo- } \\
\text { rate concepts, facts and ideas acquired from the } \\
\text { event into their courses }\end{array}$ & $\begin{array}{l}\text { Faculty will update course con- } \\
\text { tent to integrate new topic(s) } \\
\text { exposed by the event. }\end{array}$ & $\begin{array}{l}\text { Updates in the course syllabi and course } \\
\text { content }\end{array}$ \\
\hline
\end{tabular}

The second step in the assessment phase is to report, disseminate and make best use of the assessment feedback results to continuously improve the GS event effectiveness. It is important at this stage to carefully interpret the assessment data and use the findings to come-up with concrete recommendations and action plan to close the gap between expected and actual learning outcomes. Negative items appearing repeatedly in assessment surveys should be discussed in open forums to ascertain if certain patterns are developing. Some of the questions to consider when analyzing the assessment feedback results include:

- What are the implications of the assessment findings?

- How can we make better use of the information we have?

- Whose perspectives have we overlooked in the assessment process? 
- What changes to the event are needed to improve those learning outcomes that did not meet their targets?

- What actions need to be taken in future?

\section{Research Methodology and Data Collection}

Initiated during the fall semester of the 2004-2005 academic year, the guest speakers program is a special event that we have been conducting on a large (university-wide) scale, involving not only the IT department, but other participating departments as well. Prior to this, guest speakers were occasionally invited by some "volunteering" faculty members, but there were no formal planning or assessment processes. It was hoped that the program will optimize the usage of invited GS events and will make these events more visible inside and outside the university. The GS event is coordinated by a special organizing committee comprised of three faculty members. The committee's main tasks are to initiate, coordinate, plan, and assess the GS event. The committee dedicates a particular week during the last month of each semester for the GS event and encourages faculty to invite guest speakers to their classroom during that period.

For the IT department, the guest speakers participating in this program are IT practitioners and users of IT and include IT executives, managers, consultants and professionals representing various public, governmental and private organizations. Table 3 shows the list of courses that have been targeted so far by GS events.

Table 3: List of IT courses participating in GS events

\begin{tabular}{|l|l|l|}
\hline Capstone project & Systems analysis and design & Internet applications \\
\hline \hline Strategic issues in IS & Data warehousing \& mining & Distributed systems \\
\hline \hline IT project management & Management of corporate networks & Object-oriented programming \\
\hline
\end{tabular}

The guest speakers invited so far have diverse IT backgrounds and positions and are affiliated with small, medium and large corporations, both from the public as well as from the private sectors. One particular speaker was an entrepreneur who started his own IT-driven business venture. Furthermore, so far, the invited speakers have been predominately males $(95 \%)$ with only a $5 \%$ rate of female participation. This disparity in the gender distribution is also a reflection of maledominance in IT careers (especially at senior levels) in the region. In our case, all female speakers were local citizens and members of IT sections in governmental organizations.

Invited guest speakers included the head of IT research at the decision support center of the local police department; the chairman of a prominent local business group; a solution architect at a major networking company; a business developer and project manager at a major E-solutions organization; a business solutions specialist at Microsoft and IBM; a business entrepreneur of a small IT company; a manager of IT infrastructure at the local road \& transport authority; a senior software engineer of a multi-national firm, and the head of the network services unit at the local municipality, among others. This diversity in speaker backgrounds can potentially expose students to a wide spectrum of IT functions and career opportunities.

To identify suitable and diverse potential speakers (or organizations), faculty have been using a variety of resources, both internal as well as external. These include referrals from colleagues, Business Advisory Council members, current students and alumni. The local Chamber of Commerce and Industry, as well as the university Internship and Career Development Center have also been helpful in identifying appropriate speakers. Searching the internet and the local business directory, as well as direct contacts with exhibitors at major local IT trade-shows also helped 
in identifying suitable speakers. In future, we plan to establish and maintain a database of past as well as potential speakers. Such a database will include detailed information related to the speaker's name, affiliation, contact details, area(s) of expertise, credentials, and (for past speakers) summary of student feedback. A comprehensive and well maintained database can be an invaluable tool to assist faculty in identifying the most appropriate and diverse speakers (Metrejean et al., 2002).

In most cases, a suitable guest speaker is selected to fulfill a particular learning objective as reflected in the course's syllabus, which is in agreement with the alignment strategy depicted in Figure 2. In other fewer but emerging cases, a guest speaker is selected because of some unique expertise that is in some way related to the course and which can help students in order to:

- appreciate broader applications of their course material

- Gain inside perspectives on the current state and emerging trends in their course subject

- Get exposed to some best practices and lessons-learned (Vandeville, 2000) from some of the region's top IT experts, and

- Get inspired from the success stories of good decision makers, leaders and entrepreneurs, as related to their subject.

This second criteria is in accordance to the impacting strategy highlighted in Figure 2.

\section{Instrumentation and Data Collection}

Various instruments were developed to assess the learning outcomes of GS events. First, students were asked to complete immediate feedback questionnaires. These questionnaires have been refined over the past three years and comprised both structured as well as open-ended questions. The latest questionnaire (Appendix B) was divided into three sections, covering the organizational aspects of the event, the quality of the presentation, and the learning outcomes.

Second, a follow-up survey (Appendix C) was designed to determine whether students' perceptions remained the same after leaving the GS event. These surveys were distributed to senior final-year students. Each of these students has been exposed to at least two-to-three GS events.

Finally, one of the authors very recently conducted a focus group session with final-year students registered in the Capstone course. The session provided an open forum for students to discuss their perceptions towards past GS events and recommend suggestions for improvement.

During the period 2004-2006, the number of students who participated in GS events was 185 . Most of these students have been exposed to more than one guest speaker visit. Students' attendance rate during these GS events has been relatively high, ranging from $83 \%$ to $95 \%$.

\section{Research Findings and Discussion of Results}

This section discusses the detailed results of students' immediate feedback and students' followup feedback. It also shares some of the findings related to students' perception and attitude towards the GS event as reflected by threaded instructor-led discussions and by the nature of students' questions to guest speakers prior to the event.

\section{Immediate Student Feedback Responses}

Immediate student feedback data was compiled based on the latest updated questionnaire (Appendix B) that was distributed to 65 students, in classes that have just experienced GS events. Based on students' demographic profile, it is estimated that nearly half of these surveyed students 
are moderately non-traditional-aged students, who are working full-time (not necessarily in the IT field) and are financially independent.

As reported in Appendix B, the immediate student feedback responses to questions 8-10 (related to acquisition of real-world practical knowledge) were very positive. On a Likert scale from 0 to 4 (with 4 being the highest), students rated their exposure to expert's knowledge and strategies as excellent (39\%), very good (38\%), good (20\%) and satisfactory $(3 \%)$. Students agreed that their exposure to practical real-world IT knowledge was excellent $(40 \%)$, very good $(30 \%)$, good $(20 \%)$, and satisfactory $(9 \%)$. Ratings for question 10 (exposure to emerging trends and challenges in IT) were overall encouraging ( $28 \%$ - excellent; $42 \%$ - very good; $22 \%$ - good; $6 \%$ satisfactory; $1 \%$ - poor). On the other hand, the responses to question 11 (exposure to ethical and/or cultural issues related to the workplace) were less favorable. $65 \%$ of students ratings to this question were between 0 (poor) and 1 (satisfactory).

Responses to questions 12-15 (related to professional orientation) were generally very favorable, with $85 \%$ of the responses ranging from 2 (good) to 4 (excellent), with an average of 2.6/4.

Questions 16 (Would you recommend the event in other IT classes?) and 17 (Overall, are you satisfied with the event?) were yes/no questions. The responses to both of these two questions were largely in favor of inviting guest speakers. 88 per cent of students felt that guest speakers should be invited to other IT classes, while $90 \%$ expressed their satisfaction with the event. When asked if they felt cheated that three hours of textbook lecture-discussions were lost to the GS event, the majority ( $98 \%$ ) of students responded negatively.

The last three questions (19-21) were open-ended questions designed to elicit more feedback from the students regarding the merits of the GS event. The majority of the received comments were positive. Samples of students' written positive feedback included the following:

- $\quad$ "Informative: Learned new ideas about project management and SDLC, which are important for the capstone project"

- "It related what we studied so far with practical IT experience"

- "A New and different way of learning! "

- "The speakers gave excellent advice on career choices."

- "The open Q/A period was great."

- "I recommend that the event be conducted more than once a semester; It is a very beneficial event."

- $\quad$ "The fact that the speaker was young and highly ranked in his organization gives me a lot of motivation to complete my studies."

- $\quad$ "The speaker provided a revision to many topics discussed in class; but from a practical perspective."

- " "I learned what it takes to implement and maintain a Network Operations Center."

- "The practical tips related to effective IT project management were very beneficial."

- "Great usage of concrete and real-life examples."

- $\quad$ "We need to invite more guest speakers in other IT courses. It really helps to better understand the realities of IT career."

- "The speaker provided valuable information regarding his company and the usage of IT."

- "This event brought changes to the routine of regular classes. It gave us a good opportunity to meet different people and learn about their experiences."

In addition, we have received some suggestions for future improvement. Some of these suggestions included: 
- "A follow-up visit to the guest speaker's company will be extremely helpful."

- $\quad$ "The scope of the talk was very broad. I would prefer that the speaker focus on few topics and elaborate more on them."

- $\quad$ "This talk should have been formatted as a seminar targeting all IT students. "

- "The slides were cluttered with too many details."

- " $\quad$ It would have been better if the talk was conducted in a large conference room."

- $\quad$ "A shorter talk and a longer Q/A period would have been more beneficial."

- "The speaker does not have good communication skills to stimulate our interest."

- "The speaker lacks self-confidence and was indecisive."

- "The link between the real-life examples provided and what we are studying was not evident."

- $\quad$ "The speaker's presentation slides should be reused or made available for other students in future."

- "We need more events like these and more one-to-one conversations."

- "The guest speaker should have shared more information with us on career opportunities."

- "I wished all instructors conduct short follow-up discussions with students after the event."

- "We should invite renowned IT leaders, both locals and internationals."

- $\quad$ "Students should also be consulted in the choice of guest speakers and in the appropriateness of the topic."

- " It would be very helpful for faculty to interview the invited speaker and agree on the scope of the talk."

- $\quad$ "Speakers should be provided ahead of time with information related to the course objectives, and to our technical background."

The above students' comments have been very helpful for us to continuously improve the learning outcomes of future GS events. These comments can help IT educators planning similar GS events in their classrooms, as well.

Observing students' behavior and interaction during some GS events revealed that most students seemed more excited than during their regular class-time. This can be explained by the fact that they might have welcomed the change that GS events bring to their regular class-time learning. It can also be explained by the fact that many students perceive the theory taught in class as being difficult to understand and difficult to relate to reality (Bacon \& Novotny, 2002). In this respect, Karns (2005) observed that students tend to perceive a guest speaker's presentation to be relatively stimulating with less effort than other teaching methods and an experience that brings them in contact with reality - hence is more concrete and effective.

\section{Students Written Questions to Guest Speakers Prior to the Event}

In our study, students had been informed about the GS event, its goals and objectives ahead of time. They were briefed about the speaker and the topic at least two weeks prior to the guest lecture. Students were also encouraged to actively participate during the talk, and were advised to prepare a list of questions to ask in advance. In a recent experimentation, students were provided with their speaker's short biography along with the presentation's title and objectives. Each student was then asked to email the instructor two questions for the guest speaker to address. These questions were compiled, classified and forwarded to the guest speaker ahead of time. A sample list of questions for the course "Strategic issues in information systems" is shown in Appendix D. 
We found it interesting that, in our case, more than $70 \%$ of the questions forwarded to the guest speakers were career and education-related, reflecting the fact that most students seemed more geared up to learn about such topics as the worth of pursuing graduate studies and the prospects of future IT career opportunities, than learning about the topic of the talk itself.

\section{Follow-up Student Feedback Responses}

A more formal exit survey was conducted at the beginning of the 2006-2007 academic year to determine whether students' perceptions of the GS event changed over time. The follow-up survey targeted 34 students, who were instructed to fill-up the questionnaire only once. 21 of these students were registered in the project capstone course and were in their final term; while the remaining surveyed students were registered in advanced courses and were in their final year before graduation .The follow-up student feedback responses are presented in Appendix C.

For questions 1-3 (related to the usefulness and importance of the event), $\sim 83 \%$ of students' responses ranged from 3 (very much) to 4 (definitely), with an average of 3.1. None of the respondents provided a rate below 1 . This indicates that the GS events are still being perceived as beneficial as well as important for students.

Students' responses to question 4 (Did the events make you more aware of the IT professional environment?) were evenly split between 2 (somewhat) and 4 (definitely).

Responses to the yes/no question 5 (on whether they have a plan to contact a guest speaker to inquire about more information on his/her organization) were evenly split; while students' responses to question 6 revealed that most students $(67 \%)$ had no plan to contact a guest speaker to inquire about job opportunities in his/her organization.

Students' responses to question 7 (Do you recommend GS events in future?) indicated that the perception of students towards the over-all merits of the GS event marginally improved over time. 94 per cent of graduating students felt that guest speakers should be invited again to other IT classes. This is slightly higher than the corresponding $88 \%$ rating reported earlier from the immediate students' feedback survey.

Students' follow-up responses to question 8-12 were also consistent with their corresponding ratings reported earlier in the immediate feedback survey; thus confirming that the students' over-all perceptions towards the merits of the GS event did not change much over time.

The received comments in response to open-ended question 13 (Please provide below any additional comments related to GS event.) also substantiated the overall positive perception towards GS events. Further, some additional suggestions for future improvement included the following:

- "It would be helpful if guest speakers can make stronger linkage between the course content and its applications in real-world setting."

- "Stronger media presence to cover the event will be beneficial."

- "Sending open invitations to other faculty members to attend the events will make these events more distinguished."

In addition, an instructor led focus group session with graduating students in the Capstone project course revealed the following main points:

- There is a general consensus among all students that inviting IT professionals does have substantial merits and potential to boost their knowledge and professional awareness. However, 
the extent of this learning and knowledge transfer is strongly shaped by the choice of appropriate guest speakers. Students believe that it is always tempting for faculty to invite speakers that they already know; but this might not be the ideal choice. More care and efforts should be exercised to optimize the choice of invited speakers.

- Most students reiterated the earlier suggestion that a GS event should ideally be followed up by a visit to the speaker's company. They believed that there is some synergy between the two events, which leads to a better awareness about the IT professional environment. This also explains why their earlier ratings to question 4 (Did the events make you more aware of the IT professional environment?) were relatively moderate, being evenly split between 2 (somewhat) and 4 (definitely).

\section{Implications and Conclusions}

This research made use of multiple sources of evidence to assess the merits of GS events. These included immediate and follow-up survey instruments, and open discussions. The assessment findings in this study confirm the general merits of invited industry professionals as reported in the existing literature. They show that students are provided with an opportunity to discover and discuss many new IT career opportunities available to them. This also provides students with a more positive attitude towards the IT profession and enhances their self-confidence in finding a job upon graduation. The data collected indicate that the GS event helps remedy the lack of exposure of information technology students to the professional IT environment. The event provides students with invaluable real-world and practical IT knowledge. Such knowledge can either relate to a particular topic already listed in the course syllabus, or it can bring new course-related practical perspectives which are not covered by the course syllabus. These perspectives, along with the guest speaker recommendations, can be fed-back into the course syllabus to enrich its content and/or scope. Such feedback is more important than ever given the rapidly evolving nature of the IT environment.

As noted earlier, the data from this study indicates that GS events did not contribute much towards exposing students to ethical and/or cultural issues in the workplace. Such exposure is extremely important as articulated in the 2002 ACM/AIS/AITP Information Systems undergraduate curriculum report (Gorgone et al., 2002). Special attention needs to be given to this deficit. The authors believe that this shortcoming could be addressed in future by sharing with guest speakers the events' objectives, as outlined in Table 1, and requesting their support to arrange their talks accordingly.

Our research underlines the need for formal frameworks to assess the learning outcomes of GS events. Event objectives, performance criteria and measurement indicators should be clearly defined. Careful planning, judicious implementation, based on best practices, and thorough assessment are basic ingredients for successful GS events. These requirements need to be integrated in the overall assessment strategy of the program curriculum.

\section{Limitations and Further Studies}

Like other empirical studies, this study is not without its limitations. The study can be strengthened by including invited speakers as well as faculty feedback. In particular, speakers can provide very useful comments to improve the organizational aspects of future GS events and refine the event goals and objectives outlined in this study. One important limitation in this study is that guest speakers were not exposed beforehand to the objectives based on which the event will be assessed. Such exposure can potentially help speakers structure their talk so as to fulfill these objectives whenever applicable. Another limitation of this study is that the students' questionnaires did not take into account the status (part-time versus full-time) of the respondents. The authors 
believe that this factor has a definite effect on rating those event objectives which are related to professional orientation. In fact, it is expected that part-time (working) students will generally provide lower ratings than their full-time counterparts, given their prior exposure to the working environment. Future research could consider the student's status as an independent variable and investigate its impact on the rating of learning outcomes. This study can also be strengthened in future by increasing the students' sample size. Another appealing future research study could focus on refining the GS events' assessment criteria by incorporating additional objectives, as outlined in the various IS professional curriculum reports. It might also be possible to experiment with additional assessment methods that might help to further gauge students' learning outcomes. For instance, evaluating students' performance on debriefing reports or final exam questions related to the GS event can provide another assessment tool to confirm if any learning is taking place. Another study can explore and validate the students' hypothesis that combining the GS event with a follow-up company visit has a synergetic effect in enhancing their awareness about the IT professional environment. This is unlike previous studies (see for example Ormrod, 2004) which treated GS events and company visits separately. Other studies can also be conducted to confirm whether the findings of this study still hold in other IT institutions. It should be noted that the students' perception of guest speakers as teaching tools could definitely change from country to country. This was reported by Clarke III and Flaherty (2002) who researched the impact of nine teaching tools (academic readings, computer simulations, field research, guest speakers, homework problems, Internet communications, lecture, practitioner readings and videos) on students' perceptions of learning in various countries. The rating of guest speakers varied across countries, whereby it was high in the USA and low in the People's Republic of China.

Despite all these limitations, our study proposed assessment tools and research methods to assess the merits of inviting guest speakers to IT classrooms. These tools can be very useful for IT educators planning to conduct similar GS events in future. Based on the received feedback, we recommend that IT educators get involved in planning and conducting GS events, similar to the ones reported in this study.

\section{Acknowledgements}

The authors would like to acknowledge the contributions of the editor and anonymous reviewers, whose thoughtful suggestions have led to the improvement of this paper. They would like also to thank Mrs. Joan Macleod for proofreading the manuscript

\section{References}

Bacon, D.R. \& Novotny, J. (2002). Exploring achievement striving as a moderator of the grading leniency effect. Journal of Marketing Education, 24 (1), 4-14.

Berlak, A. (1999). Taking it personally: Encountering racism in a cultural diversity course (ERIC Document Accession No. ED444978).

Boyer, E. (1990). Scholarship reconsidered: Priorities of the professoriate $\left(1^{\text {st }} \mathrm{ed}.\right)$. The Carnegie Foundation for the Advancement of Teaching, San Francisco, CA: Jossey-Bass Publishers.

Bransford, J., Brown, A., \& Cocking, R. (1999). How people learn: Brain, mind, experience, and school. Committee on Developments in the Science of Learning, National Research Council. Retrieved November 16, 2005 from http://www.nap.edu/html/howpeople1

Butler, R. (1997). Using gender balance to enhance teaching effectiveness. Business Communication Quarterly, 60, 93-100.

Caputo, D., Kovacs, P. \& Turchek, J. (2006). Defining the essential skill and functional areas of study in information technology as measured by a survey of field professionals, Information Systems Education Journal, 4 (6), 3-8. 
Clarke III, I. \& Flaherty, T.B. (2002). Teaching internationally: Matching part-time MBA Instructional tools to host country student preferences. Journal of Marketing Education, 24 (3), 233-242.

Clarke, J. \& Gibson-Sweet, M. (1998). Enterprising futures: Training and education for small businesses. Education and Training, 40 (3), 102-108.

Cleary, T. \& Zimmerman, B.J. (2000). Self-regulation differences during athletic practice by experts, nonexperts, and novices. Journal of Applied Sport Psychology, 13, 61-82.

Cooper, S., Bottomley, C. \& Gordon, J. (2004). Stepping out of the classroom and up the ladder of learning. Industry and Higher Education, 18(1), 11-22.

Davis, B. G. (1993). Tools for teaching. San Francisco, CA: Jossey Bass Publishers.

Glenwick, D. \& Chabot, D. (1991). The undergraduate clinical child psychology course: Bringing students to the real world and the real world to students. Teaching of Psychology, 18, 21-24.

Gordon, G. (1999). Managing the changes inherent in developing the learning society: Issues, choices and strategies. Quality Assurance in Education, 7 (3), 141-149.

Gorgone, J., Davis, G., Valacich, J., Topi, H., Feinstein, D. \& Longenecker, H. (2002). IS 2002: Model curriculum and guidelines for undergraduate degree programs in Information Systems, Retrieved November 21, 2005, from http://www.acm.org/education/is2002.pdf

Gustafson, R. (1998). Marketers all need to go back to school- to help out. Marketing News, 32 (4), 9.

Guth, L., Hewitt-Gervais, C., Smith, S. \& Fisher, M. (2000). Student attitudes toward AIDS and homosexuality: The effects of a speaker with HIV. Journal of College Student Development, 41, 503-512.

Heck, S. (1994). Bringing professionals into the classroom: "Faculty for a day". Teaching Public Relations (TPR) Monograph 37 (June 1994). Association for Education in Journalism and Mass Communication.

Karns, G. L. (2005). An update of marketing student perceptions of learning activities: structure, preferences and effectiveness. Journal of Marketing Education, 27 (2), 163-171.

Kim, Y., Shim, S.J., \& Yoon, K.P. (1999). Bridging the gap between practitioner-educator perceptions of key IS issues for effective implementation of IS curriculum. Proceedings of 1999 IRMA International Conference, Hershey, PA. 513-518

Lambert, R. (2003). Lambert review of business-university collaboration. HM treasury, London. Retrieved November 21, 2005 from http://www.lambertreview.org.uk

Maglitta, J. (1996). IT schools need improvement. Computerworld, 30(8), 78-83.

Markus, M. L. (2001). Toward a theory of knowledge reuse: Types of knowledge reuse situations and factors in reuse success. Journal of Management Information Systems, 18 (1), 57-93.

Metcalfe, M., Wilson, J., \& Joham, C. (2002). Critique skills as the core competency of IS academics. Proceedings of the Informing Science + IT Education Conference, 1067-1081. Available at http://proceedings.informingscience.org/IS2002Proceedings/papers/metca100critiq.pdf

Metrejean, C., Pittman, J. \& Zarzeski, M. (2002). Guest speakers: reflections on the role of accountants in the classroom. Accounting Education, 11 (4), 347-364.

Mullins, P. (2001). Using outside speakers in the classrooms. Observer, 14 (8). Retrieved November 21, 2005, from http://www.psychologicalscience.org/observer/1001/tips.html

Murray, G. \& Bollinger, D. (2001). Developing cross-cultural awareness: Learning through the experience of others. TESL Canada Journal, 19, 62-72.

Neville, K. \& Adam, F. (2003). Integrating theory and practice in education with business games. Informing Science, 6, 61-73. Available at http://inform.nu/Articles/Vol6/v6p061-073.pdf

Ohl, C. (1991). Networking through professional organizations. In J. V. Turk (Ed.), Learning to teach: What you need to know to develop successful career as a public relations educator (p. 140). New York: Public Relations Society of America. 
Ormrod, N.G. (2004). The use of guest speakers, company visits and professional bodies' events in the curriculum. Research paper series No 4, Manchester Metropolitan University Cheshire, Retrieved June 20, 2006 from http://www.cheshire.mmu.ac.uk/bms/home/research/pdf-doc/doc-06.pdf

Payne, B. K., Sumter, M., \& Sun, I. (2003). Bringing the field into the criminal justice classroom: Field trips, ride-alongs, and guest speakers. Journal of Criminal Justice Education, 14 (2), 327.

Rae, J., Roberts, C., \& Taylor, G. (2006). Collaborative learning: A connected community approach, Issues in Informing Science and Information Technology, 3, 520-528. Available at http://informingscience.org/proceedings/InSITE2006/IISITRae204.pdf

Sandy, L. R. (1998). The permeable classroom. Journal on Excellence in College Teaching, 9(3), 47-63.

Shore, D.A. (1993). Everything according to plan: Success with faculty. Association Management, 44, 113120.

Siemens, G. (2004). Connectivism: A learning theory for the digital age. Retrieved February 15, 2007 from http://www.elearnspace.org/Articles/connectivism.htm

Sivan, A., Leung, R.W., Woon, C. \&Kember, D. (2000). An implementation of active learning and its effect on the quality of student learning. Innovations in Educational and Training International, 37 (4), 381-389.

Sniezek, T. (2005). Avoiding the pitfalls of the invited speaker. Exchanges: The on-line journal of teaching and learning in the CSU, The institute of teaching and learning. Retrieved November 16, 2005, from http://www.exchangesjournal.org/classroom/1207_Sniezek.html

Vandeville, J. V. (2000). Organizational learning through the collection of "Lessons learned". Informing Science, 3 (3), 127-133. Available at http://inform.nu/Articles/Vol3/v3n3p127-133.pdf

Viehland, D. (2005). ISExpertNet: Facilitating knowledge sharing in the Information Systems academic community, Issues in Informing Science and Information Technology, 2, 441-451. Available at http://2005papers.iisit.org/I36f30Vieh.pdf

Wortmann, G. (1992). An invitation to learn: guest speakers in the classroom. The Science Teacher, 59 (2), $19-22$. 


\section{Appendix A}

\section{Best Policies and Practices}

\section{Initiation and planning phase}

- Schedule the event at the end of the semester to equip students with necessary background material

- Strongly encourage faculty to actively participate in inviting guest speakers

- Explore many resources to identify suitable guest speakers, including fellow faculty, graduated students, students' referrals, business advisory council, authors, and personal contacts

- Ensure that the speaker is credible: do not settle for the first person who happens to be available.

- Maintain a database of potential courses and associated speakers/organizations that are willing to participate in the event

- Maintain a database of assessment feedback and ratings of previous guest speakers. This can guide on the appropriateness of inviting these speakers again

- Contact guest speakers ahead of time to probe availability and willingness to participate in the event

- Debrief students about the event, its expectations as well as the background of the guest speaker ahead of time. Prior discussions with the class can promote students' participation

- Set rules and expectations regarding appropriate behavior and classroom etiquette

- Whenever applicable, inform students that the final exam will have a component to assess them on topics related to the event. Alternatively inform students that they will be asked to provide a debriefing summary/reflections paper related to the event

- Explore the opportunity to involve volunteering students in the planning of the event

- Ask students to provide a list of questions to be forwarded to guest speakers prior to the event so as to make the speakers aware of some of students' interests

- Along with the official invitation, forward to guest speakers information related to logistics, course syllabus, number of students and their background/general profile, as well as event's objectives, students' questions, and inquiries about special equipment needs

- Make sure that the speakers' talk will not be diverted towards a marketing campaign preaching his/her organization

- Encourage speakers to share with students their personal experiences, successes and disappointments

- Encourage students to stay after the talk and interact with the speaker

- Publicize the event in the campus (posters/banners), and local newspapers if desired

- Inform administrators and campus security about the event and the schedule of the talks ahead of time

\section{Execution phase}

- Ask students to take notes during the presentation to give the event full teaching value and credibility

- Allow enough time for questions and answers period

- Show appreciation to the guest speaker and allow time to recap on the presentation and to relate it to the course material

- Allow enough time for an informal refreshment period. This can provide both faculty and students with a good opportunity to informally interrelate with the guest speaker

- To make best use of the invited speaker, it is a good practice for the faculty to intervene during the talk, if needed, and ask specific questions to re-vector the talk towards its desired outcomes

\section{Assessment phase}

- Establish event's goals and objectives and outline performance criteria and measurement indicators, similar to those outlined in this research

- Conduct a follow-up meeting with students to recap on the main topics discussed and solicit students' feedback

- Use a variety of assessment methods at different points in time

- Carefully analyze, and interpret the results. Use these for continuous improvement 


\section{Appendix B}

\section{Immediate Student Feedback Survey Results}

\begin{tabular}{|c|c|c|c|c|c|c|c|}
\hline Item & Criterion & 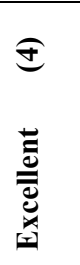 & 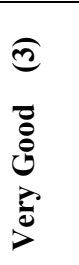 & 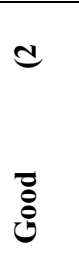 & 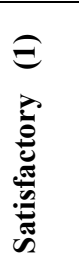 & $\widehat{\ominus}$ & $\underset{\mathrm{Z}}{\ll}$ \\
\hline & Organizational aspects of the event & & & & & & \\
\hline 1 & Time appropriateness of the event & $11 \%$ & $57 \%$ & $28 \%$ & $4 \%$ & - & - \\
\hline 2 & Appropriateness of the event's venue & $16 \%$ & $43 \%$ & $36 \%$ & $5 \%$ & - & - \\
\hline 3 & Introduction made by the lecturer & $22 \%$ & $52 \%$ & $22 \%$ & $4 \%$ & - & - \\
\hline 4 & Time allocated for the presentation & $11 \%$ & $37 \%$ & $40 \%$ & $9 \%$ & $1 \%$ & $2 \%$ \\
\hline \multirow[t]{2}{*}{5} & Time allocated for $\mathrm{Q} / \mathrm{A}$ & $16 \%$ & $36 \%$ & $31 \%$ & $9 \%$ & $7 \%$ & $1 \%$ \\
\hline & Quality of the speaker's presentation & & & & & & \\
\hline 6 & $\begin{array}{l}\text { Guest speaker approach and clarity in deliver- } \\
\text { ing the presentation }\end{array}$ & $8 \%$ & $60 \%$ & $28 \%$ & $4 \%$ & - & - \\
\hline \multirow[t]{2}{*}{7} & Guest speaker enthusiasm about the subject & $25 \%$ & $44 \%$ & $29 \%$ & $1 \%$ & - & $1 \%$ \\
\hline & $\begin{array}{l}\text { Student learning objective: } \\
\text { Real-world practical knowledge }\end{array}$ & & & & & & \\
\hline 8 & $\begin{array}{l}\text { Exposure to expert's knowledge and strate- } \\
\text { gies }\end{array}$ & $39 \%$ & $38 \%$ & $20 \%$ & $3 \%$ & - & - \\
\hline 9 & $\begin{array}{l}\text { Exposure to practical real-world IT knowl- } \\
\text { edge }\end{array}$ & $40 \%$ & $30 \%$ & $20 \%$ & $9 \%$ & - & $1 \%$ \\
\hline 10 & $\begin{array}{l}\text { Exposure to emerging trends and challenges } \\
\text { in IT }\end{array}$ & $28 \%$ & $42 \%$ & $22 \%$ & $6 \%$ & $1 \%$ & $1 \%$ \\
\hline \multirow[t]{2}{*}{11} & $\begin{array}{l}\text { Exposure to ethical and/or cultural issues } \\
\text { related to the workplace }\end{array}$ & $3 \%$ & $9 \%$ & $17 \%$ & $17 \%$ & $48 \%$ & $6 \%$ \\
\hline & $\begin{array}{l}\text { Student learning objective: } \\
\text { Professional orientation }\end{array}$ & & & & & & \\
\hline 12 & $\begin{array}{l}\text { Exposure to new IT career paths and oppor- } \\
\text { tunities }\end{array}$ & $23 \%$ & $36 \%$ & $29 \%$ & $6 \%$ & - & $6 \%$ \\
\hline 13 & $\begin{array}{l}\text { Awareness about IT competencies that are } \\
\text { mostly needed in the marketplace }\end{array}$ & $28 \%$ & $34 \%$ & $28 \%$ & $6 \%$ & - & $4 \%$ \\
\hline 14 & $\begin{array}{l}\text { Acquisition of a more positive attitude to- } \\
\text { wards the IT profession }\end{array}$ & $26 \%$ & $36 \%$ & $25 \%$ & $6 \%$ & $3 \%$ & $4 \%$ \\
\hline 15 & $\begin{array}{l}\text { Degree of informal networking with the guest } \\
\text { speaker }\end{array}$ & $14 \%$ & $29 \%$ & $37 \%$ & $15 \%$ & $3 \%$ & $2 \%$ \\
\hline
\end{tabular}

\begin{tabular}{|l|l|l|l|}
\cline { 3 - 4 } Item & & YES & NO \\
\hline 16 & Would you recommend the event in other IT classes? & $88 \%$ & $12 \%$ \\
\hline 17 & Overall, are you satisfied with the event? & $90 \%$ & $10 \%$ \\
\hline 18 & $\begin{array}{l}\text { Do you feel "cheated" that three hours of textbook lecture- } \\
\text { discussions were "lost" to the speaker event? }\end{array}$ & $2 \%$ & $98 \%$ \\
\hline
\end{tabular}

19. What did you like about the event?

20. What could have been different?

21. Please add below any other comments you wish to make about the event 


\section{Appendix C}

\section{Follow-up Student Feedback Survey Results}

\begin{tabular}{|c|c|c|c|c|c|c|}
\hline$\stackrel{\Xi}{\Xi}$ & & 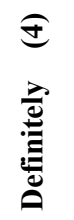 & 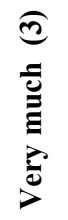 & 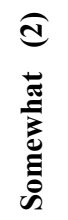 & 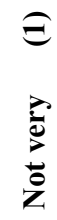 & 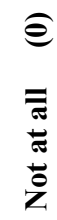 \\
\hline 1 & Have you benefited from the guest speaker events? & $21 \%$ & $62 \%$ & $12 \%$ & $5 \%$ & - \\
\hline 2 & Do you think that the events were useful? & $30 \%$ & $53 \%$ & $15 \%$ & $2 \%$ & - \\
\hline 3 & Do you think that the events were important? & $38 \%$ & $44 \%$ & $15 \%$ & $3 \%$ & - \\
\hline 4 & $\begin{array}{l}\text { Did the events make you more aware of the IT professional environ- } \\
\text { ment? }\end{array}$ & $27 \%$ & $33 \%$ & $35 \%$ & - & $5 \%$ \\
\hline
\end{tabular}

\begin{tabular}{|c|l|c|c|}
\cline { 3 - 4 } & & YES & NO \\
\hline 5 & $\begin{array}{l}\text { Is (was) there a plan to contact a guest speaker to inquire about more information on his/her } \\
\text { organization? }\end{array}$ & $47 \%$ & $53 \%$ \\
\hline 6 & $\begin{array}{l}\text { Is (was) there a plan to contact a guest speaker to inquire about job opportunities in his/her } \\
\text { organization? }\end{array}$ & $33 \%$ & $67 \%$ \\
\hline 7 & Do you recommend guest speaker events in future? & $94 \%$ & $6 \%$ \\
\hline
\end{tabular}

For the following objectives, assess the degree of learning as achieved from your previous experience with guest speaker events:

\begin{tabular}{|c|c|c|c|c|c|c|c|}
\hline$\stackrel{\Xi}{\Xi}$ & Objective & 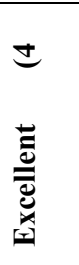 & $\begin{array}{l}\text { ల్ర } \\
\text { D } \\
0 \\
0 \\
0 \\
0 \\
0 \\
0\end{array}$ & 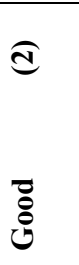 & 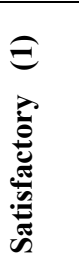 & $\begin{array}{l}\text { อ } \\
: \\
:\end{array}$ & $\overleftrightarrow{\mathbf{z}}$ \\
\hline 8 & $\begin{array}{l}\text { Acquisition of practical real-world IT knowl- } \\
\text { edge }\end{array}$ & $15 \%$ & $49 \%$ & $36 \%$ & - & - & - \\
\hline 9 & Ability to identify new trends in IT & $18 \%$ & $30 \%$ & $41 \%$ & $11 \%$ & - & - \\
\hline 10 & $\begin{array}{l}\text { Ability to recognize new IT career paths and } \\
\text { opportunities }\end{array}$ & $15 \%$ & $44 \%$ & $38 \%$ & - & $3 \%$ & - \\
\hline 11 & $\begin{array}{l}\text { Ability to identify what areas of IT compe- } \\
\text { tencies are important }\end{array}$ & $15 \%$ & $53 \%$ & $26 \%$ & $3 \%$ & $3 \%$ & - \\
\hline 12 & $\begin{array}{l}\text { Acquisition of a more positive attitude to- } \\
\text { wards the IT profession }\end{array}$ & $18 \%$ & $50 \%$ & $29 \%$ & 0 & $3 \%$ & - \\
\hline
\end{tabular}

13. Please provide below any additional comments related to guest speaker events. 


\section{Appendix D}

\section{Sample of students' questions to the guest speaker classified by types (Course: strategic issues in IS)}

\begin{tabular}{|c|c|}
\hline Question type & Question description \\
\hline Talk-related & $\begin{array}{l}\text { - What are the key success factors in your organization? How does IS } \\
\text { help you achieve these? } \\
\text { - Do you think that it is possible to depend on long term IS strategic } \\
\text { planning in this ever changing dynamic world? } \\
\text { - What type of business strategy does your company pursue? How does } \\
\text { IS strategy relate to your business strategy? }\end{array}$ \\
\hline Career-related & $\begin{array}{l}\text { - What qualifications and skill-sets helped you reach this position? } \\
\text { - What type of knowledge, skills and training is your department mostly } \\
\text { looking for in its recruiting process? }\end{array}$ \\
\hline Education-related & $\begin{array}{l}\text { - If I wanted to pursue graduate studies, would it be better to go for a } \\
\text { Masters Degree in IT or an MBA? } \\
\text { I want to pursue a Masters degree in IT. Which concentration you think } \\
\text { is most demanded in the job market? } \\
\text { - Are two years of IT experience more valuable than two years spent to } \\
\text { - } \quad \text { What an IT graduate degree? } \\
\text { business environment? }\end{array}$ \\
\hline Work-related & $\begin{array}{l}\text { - Which criteria you think are most important when acquiring an Infor- } \\
\text { mation System? } \\
\text { - What was the last Information System that your company acquired? } \\
\text { How successful was it? } \\
\text { Have you faced any failure experience in previous projects? If yes, of } \\
\text { what type and how did you cope with it? }\end{array}$ \\
\hline
\end{tabular}

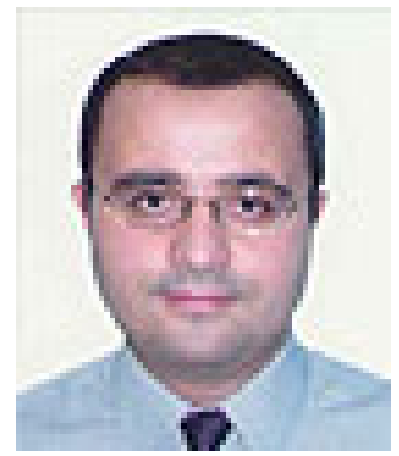

\section{Biographies}

Faouzi Kamoun is an Assistant Professor and Assistant Dean in the College of Information Technology at the University of Dubai (UD). He received his Ph.D., in Electrical and Computer Engineering from Concordia University, and his MBA from McGill University. He was the recipient of UD's best faculty award in 2004, and Nortel Networks CEO top talent awards in 2000 and 2001.

Dr Kamoun is a member of the editorial board of the Journal of Information Technology. He taught various courses in the areas of Information Systems, programming, project management, networks' management and internet security. He published around thirty papers in International Journals and Conference proceedings. He is currently engaged in several initiatives to assess students learning outcomes at the College of IT. 


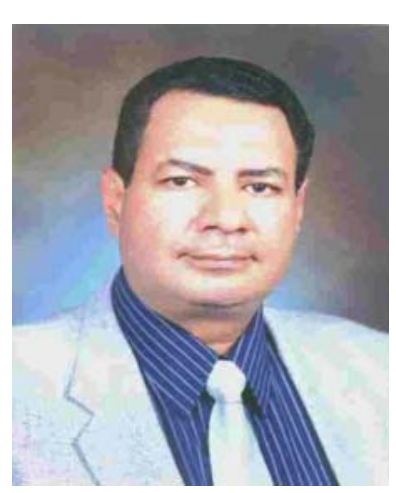

Said Selim is Professor and Dean of the College of Information Technology, University of Dubai (UD) UAE.

Professor Selim has many years of experience working in the Gulf and while this is an area of the world that he has made positive contributions to, he has been careful to maintain contact with colleagues throughout the world. Throughout his career he has been in the enviable and challenging position of being a pioneer in the establishment and development of computer science and Information Technology programs in all the universities where he has had the privilege of making a contribution.

His main research areas include computer algorithms, scheduling problems and timetables, simulation and modeling, graph algorithms, and computing in Education 